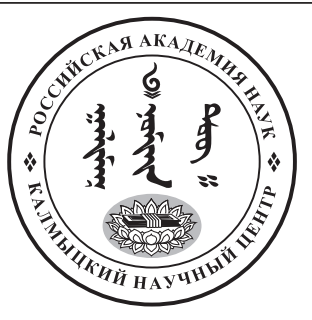

Published in the Russian Federation

Oriental Studies (Previous Name: Bulletin of the Kalmyk Institute

for Humanities of the Russian Academy of Sciences)

Has been issued as a journal since 2008

ISSN: 2619-0990; E-ISSN: 2619-1008

Vol. 13, Is. 4, pp. 1121-1134, 2020

DOI: $10.22162 / 2619-0990-2020-50-4-1121-1134$

Journal homepage: https://kigiran.elpub.ru

УДК 811.512

DOI: 10.22162/2619-0990-2020-50-4-1121-1134

\title{
Как изменилась форма показателя множественного числа в тюркских языках за последние 150 лет
}

\section{Юлия Викторовна Норманская ${ }^{1}$, Анар Ахметбековна Гаджиева}

${ }^{1}$ Институт языкознания РАН (д. 1, стр. 1, Большой Кисловский пер., 125009 Москва, Российская Федерация), Институт системного программирования РАН им. В. П. Иванникова (д. 25, ул. Александра Солженицына, 109004 Москва, Российская Федерация) доктор филологических наук, заведующая iD 0000-0002-2769-9187.E-mail: julianor@mail.ru

${ }^{2}$ Военный университет (д. 14, ул. Большая Садовая, 125047 Москва, Российская Федерация) кандидат филологических наук

(iD) 0000-0003-0314-0300. E-mail: nuanar@yandex.ru

(C) КалмНЦ РАН, 2020

(C) Норманская Ю. В., Гаджиева А. А., 2020

Аннотация. Введение. Как показывают работы последних лет, у ученых нет единого мнения о происхождении формы множественного числа в кыпчакских языках, ср. К. М. Мусаев высказывает гипотезу о том, что пракыпчакская форма этого аффикса была *-tar/*-ter, по мнению О. А. Мудрака, исходным был вариант *-lar/*-ler. Действительно, на материале современных данных в кыпчакских языках для типов основ на ${ }^{*}-n,{ }_{-}{ }_{-} \eta,{ }^{*}-m$ и на ${ }_{-}-C$ реконструировать форму аффикса множественного числа не удается. Оказывается, что и общетюркская реконструкция того или иного показателя для этих типов основ не очевидна. Цели исследования: на основании анализа современных языков и первых кириллических книг 1) реконструировать пракыпчакскую и пратюркские формы аффикса множественного числа в словах с разными типами основ, 2) датировать изменения суффиксов, произошедшие в ряде языков, 3) установить, имели ли эти изменения ареальный характер. Материальь и методы: грамматики современных тюркских языков, первые кириллические книги на татарском, башкирском, казахском, алтайской, телеутском, тубаларском языках, их анализ проводится с помощью сравнительно исторического метода. Результаты: было установлено, что в большинстве тюркских языков сохранилось позднепратюркское состояние аффикса множественного числа без изменений. В части кыпчакских языков (казахском, киргизском, некоторых диалектах башкирского и алтайского), которые находились на стыке территорий «-lVr vs. - $t V r »$, произошла замена показателей *-lVr

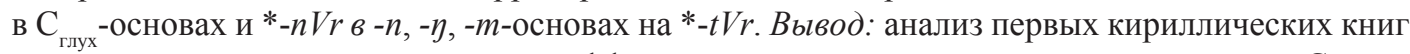
позволил установить, что изменения аффикса множественного в кыпчакских языках в $\mathrm{C}_{\text {глух }}$ - $n$, - $\eta$, -m-основах происходили в XIX в. в результате контактов с носителями кыргызских языков. 
Ключевые слова: казахский язык, кычакские языки, первые кириллические книги, аффикс множественного числа, сравнительно-историческое языкознание, ареальные процессы в лингвистике, языковые контакты.

Для цитирования: Норманская Ю. В., Гаджиева А. А. Как изменилась форма показателя множественного числа в тюркских языках за последние 150 лет // Oriental Studies. 2020. Т. 13. № 4. C. 1121-1134. DOI: 10.22162/2619-0990-2020-50-4-1121-1134

UDC 811.512

DOI: $10.22162 / 2619-0990-2020-50-4-1121-1134$

\title{
How the plural affix was changed in the Turkic languages over the last 150 years
}

\author{
Yulia V. Normanskaya ${ }^{1}$, Anar A. Gadzhieva
}

${ }^{1}$ Institute of linguistic RAS (h.1, build. 1, Big Kislovskij., 125009 Moscow, Russian Federation), Ivannikov's Institute of System Programming (h. 25, Alexander Solzhenitsin str., 109004, Moscow, Russian Federation)

Dr. Sc. (Philology), Head

iD 0000-0002-2769-9187.E-mail: julianor@mail.ru

${ }^{2}$ Military university (h. 14, Bolshaya Sadovaya str., 125047 Moscow, Russian Federation)

Cand. Sc. (Philology)

iD 0000-0003-0314-0300.E-mail: nuanar@yandex.ru

\author{
(C) KalmSC RAS, 2020 \\ (C) Normanskaya Yu. V., Gadzhieva A. A., 2020
}

\begin{abstract}
Introduction. As recent research works show, scholars tend to disagree about the origin of the Kipchak plural form. K. M. Musaev hypothesizes that the Proto-Kipchak form of this affix was

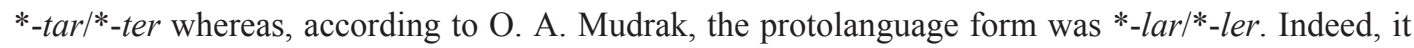
seems impossible to reconstruct the form of the plural affix for the $*_{-} n, *_{-} \eta, *_{-} m, *_{-}$- - stem words based on the modern data for the Kipchak languages. Furthermore, the Proto-Turkic reconstruction of the plural affix for these stems is also unclear. Purpose of research: It follows that a systematic analysis of the forms of the plural affix with different stems in the first books in the Kipchak languages (Tatar, Bashkir, Kazakh, Teleut, Tubalar) will help to 1) reconstruct their Proto-Kipchak and Proto-Turkic forms, 2) date the changes in the suffixes, 3) determine if these changes were areal in nature. Materials and methods: The grammars of the modern Turkic languages as well as the first Cyrillic books in Tatar, Bashkir, Kazakh, Altai, Teleut, Tubalar have been analyzed using a comparative historical method. Results: The analysis reveals that the late Proto-Turkic form of the plural affix remained unchanged in most of the Turkic languages. In some of the Kipchak languages (Kazakh, Kyrgyz, certain dialects of Bashkir and Altai) located at the junction of the "-lVr-form vs.$t V r$-form of the plural affix" territories, the *-lVr-form (in voiceless $*_{-} \mathrm{C}$-stems) and the $*_{-} n V r$-form (in *-n, *- $\eta, *_{-} m$-stems) changed into *-tVr. Conclusion: The material of the first Kazakh books in Cyrillic shows that the change in the Kipchak plural affix in voiceless $*_{-}$C-stem and in $*_{-} n, *_{-} \eta$, $*_{-} m$-stem words was quite late, took place due to contacts with the Kyrgyzs, and was not yet complete at the end of the $19^{\text {th }}$ century.
\end{abstract}

Keywords: Kazakh language, Kipchak languages, first Cyrillic books, plural affix, Comparativehistorical linguistics, Areal linguistic, language contacts

For citation: Normanskaya Yu. V., Gadzhieva A. A. How the plural affix changed in the Turkic languages over the last 150 years // Oriental Studies. 2020. Vol. 13(4): 1121-1134. (In Russ.). DOI: 10.22162/2619-0990-2020-50-4-1121-1134 


\section{Введение}

Как показывают работы последних лет, у ученых нет единого мнения о происхождении пракыпчакской формы множественного числа, ср. [Турсунова 2012: 94]. Даже авторы [СИГТЯ 2002] высказывают разные гипотезы о происхождении этого аффикса в общетюркском языке. К. М. Мусаев высказывает гипотезу [СИГТЯ 2002: 301] о том, что пракыпчакская форма этого аффикса была *-tar $/ *$-ter, и он был образован от глагола *tar-a- 'распространяться' на общетюркском уровне. По его мнению, формы на *-lar $/ *$-ler возникли путем морфонологических преобразований. Но О. А. Мудрак на материале анализа древнетюркских памятников и якутского языка приходит к выводу [СИГТЯ 2002: 603], что, наоборот, вариант *-lar/*-ler был исходным, а вариант *-tar $/ *$-ter возник как результат сложения двух аффиксов *-t- показателя множественности для одушевленных лиц и *-lar/*-ler. О. А. Мудрак приводит реальные примеры функционирования одновременно двух аффиксов в названиях имен в древне-тюркских памятниках и у одушевленных лиц в якутском языке. Такие примеры выявлены и нами в первых кириллических книгах на якутском языке, ср. уол-ат-тар 'мальчик-P1-Pl'в виртуальной лаборатории Lingvodoc $^{1}$. А. В. Дыбо в [СИГТЯ 2006: 229] соглашается с гипотезой О. А. Мудрака.

Но при этой гипотезе, которая представляется справедливой, все же не вполне ясно, какой именно показатель использовался в той или иной позиции в дочерних тюркских праязыках.

\section{1. Показатели множественного числа} в современных тюркских языках

Суммируем данным по конкретным языкам, приведенные в [СИГТЯ 2002], в виде таблицы, добавив предложения по реконструкции показателя, употребляемого в дочерних тюркских праязыках в том или ином типе основ (см. табл. 1).

Таблица 1. Рефлексы *-lar/*-ler в современных тюркских языкахи диалектах в зависимости от типа основы

[Table $1 . *_{-}$lar $/ *_{-}$ler reflexes in modern Turkic languages and dialects depending on the type of word's base]

\begin{tabular}{|c|c|c|c|c|}
\hline & \multicolumn{4}{|c|}{ Тип основ } \\
\hline Языки & $-n,-\eta,-m$ & $-V$ & $-j$ & $-C_{2}$ \\
\hline \multicolumn{5}{|c|}{ Огузские } \\
\hline & $*_{-n V r}$ & $*_{-l} l V r$ & $*_{-l} l V r$ & $*_{-l} l V r$ \\
\hline турец.диал. & $-n V r$ & $-l V r$ & $-l V r$ & $-l V r$ \\
\hline гагауз. & $-n V r$ & $-l V r$ & $-l V r$ & $-l V r$ \\
\hline крым.-татар. & $-l V r$ & $-l V r$ & $-l V r$ & $-l V r$ \\
\hline азерб. & $-n V r$ & $-l V r$ & $-l V r$ & $-d V r$ \\
\hline туркм. диал. & $-n V r$ & $-l V r$ & $-l V r$ & $-l V r$ \\
\hline салар. & $-n V r$ & $-l V r$ & $-l V r$ & $-l V r$ \\
\hline \multicolumn{5}{|c|}{ Карлукско-уйгурские } \\
\hline & $*_{-l V r}$ & $*_{-l V r}$ & $*_{-l V r}$ & $*_{-l} l V r$ \\
\hline узб. & $-l V r$ & $-l V r$ & $-l V r$ & $-l V r$ \\
\hline уйг. & $-l V r$ & $-l V r$ & $-l V r$ & $-l V r$ \\
\hline \multicolumn{5}{|c|}{ Кыргызские } \\
\hline & $*_{-n V r}$ & $*_{-l V r}$ & $*_{-l} l V r$ & $*_{-t} t V r$ \\
\hline хак. & $-n V r$ & $-l V r$ & $-l V r$ & $-t V r$ \\
\hline шор. & $-n V r$ & $-l V r$ & $-l V r$ & $-t V r$ \\
\hline
\end{tabular}

1 Lingvodoc [электронный pecypc] // URL: http://lingvodoc.ispras.ru/dictionary/2181/5816/ perspective/2181/5819/view (дата обращения: 25.08.2020). 
Oriental Studies. 2020. Vol. 13. Iss. 4

\begin{tabular}{|c|c|c|c|c|}
\hline чулым. & $-n V r$ & $-l V r$ & $-l V r$ & $-t V r$ \\
\hline сар.-юг. & $-n V r$ & $-l V r$ & $-l V r$ & $-t / d V r$ \\
\hline \multicolumn{5}{|c|}{ Кыпчакские } \\
\hline & $?$ & $*-l V r$ & $*-l V r$ & ? \\
\hline караим. & $-l V r$ & $-l V r$ & $-l V r$ & $-l V r$ \\
\hline ккалп. & $-l V r$ & $-l V r$ & $-l V r$ & $-l V r$ \\
\hline кбалк. & $-l V r$ & $-l V r$ & $-l V r$ & $-l V r$ \\
\hline кум. & $-l V r$ & $-l V r$ & $-l V r$ & $-l V r$ \\
\hline ног. & $-n V r$ & $-l V r$ & $-l V r$ & $-l V r$ \\
\hline тат. & $-n V r$ & $-l V r$ & $-l V r$ & $-l V r$ \\
\hline башк. сев-зап. & $-n V r$ & $-l V r$ & $-l V r$ & $-l V r$ \\
\hline башк. южн. & $-n V r$ & $-l V r$ & $-l V r$ & $-l V r$ \\
\hline башк. вост. & $-d V r$ & $-l V r$ & $-\delta V r$ & $-t V r$ \\
\hline казах. & $-d V r$ & $-l V r$ & $-l V r$ & $-t V r$ \\
\hline кирг. & $-d V r$ & $-l V r$ & $-l V r$ & $-t / d V r$ \\
\hline алт. & $-d V r$ & $-l V r$ & $-l V r$ & $-t V r$ \\
\hline \multicolumn{5}{|c|}{ Тобаские } \\
\hline & ${ }^{*}-n V r$ & $*_{-l V r}$ & ${ }^{*}-l V r$ & ${ }^{*} t V r$ \\
\hline тоф. & $-n V r$ & $-l V r$ & $-l V r$ & $-t V r$ \\
\hline тув. & $-n V r$ & $-l V r$ & $-l V r$ & $-t V r$ \\
\hline \multicolumn{5}{|c|}{ Якутский } \\
\hline & ${ }^{*}-n V r$ & $*-l V r$ & $*_{-} d V r$ & ${ }^{*}-t V r$ \\
\hline якут. & $-n V r$ & $-l V r$ & $-d V r$ & $-t V r$ \\
\hline
\end{tabular}

Как видно из таблицы, во всех тюркских дочерних праязыках, за исключением кыпчакских, в каждом из типов основ вариант аффикса реконструируется достаточно надежно. А в кыпчакских языках для типов основ на $-n,-\eta,-m$ и на - $C$ это сделать не удается. Оказывается, что и общетюркская реконструкция того или иного показателя для типов основ на $-n,-\eta,-m$ и на $-C$ не очевидна и в определенной степени зависит от решения по кыпчакским языкам, поскольку в обоих случаях есть два конкурирующих аффикса, которые сохранились в этой позиции в разных дочерних праязыках из разных групп.

2. Показатели множественного числа в первых кириллических книгах на кыпчакских языках

В связи с этой проблемой наше внимание привлекли первые кириллические книги на кыпчакских языках, подготовленные в рамках деятельности Переводческой комиссии, учрежденной при братстве св. Гурия в Казани, начиная с 1869 г. до 1917 гг. Как показывают исследования, проведенные под руководством Ю. В. Норманской, первые кыпчакские кириллические книги, изданные в этот период, были подготовлены на высоком научном уровне, и их системные отличия от современных литературных языков связаны, в первую очередь, с тем, что они были написаны на диалектах соответствующих языков, ср. описания графо-фонетических и морфологических систем в татарском [Нуриева 2015; Нуриева 2017; Норманская, Нуриева 2018], башкирском [Каримова, Латыпова 2016; Норманская, Каримова, Экба 2017; Экба, Норманская, Каримова 2019], казахском [Шаймердинова 2016; Дыбо, Норманская 2016; Гаджиева 2019] языках.

Анализ аффиксов множественного числа в первых кириллических книгах на казахском языке показал, что в ряде случаев в них представлена другая форма показателя: ср. зап. каз. турганнарга [Премудрости 1891] — лит. каз. тұрzандарzа 'стоящим'; Жазыкларымды [Премудрости 1891] лит. каз. Жазықтарымды 'грехи мои'; вост. каз. священниклерди [Крещение 1892] лит. каз. священниктердi 'священников' и другие примеры. На основании этого мы предположили, что системный анализ форм аффикса множественного числа в разных типах основ в первых книгах на кыпчакских языках позволит 1) реконстрируировать их пракыпчакскую форму, 2) датировать из- 
менения суффиксов, произошедшие в ряде языков, 3) установить, имели ли эти изменения ареальный характер.

Для анализа были привлечены следующие первые книги (часть из них доступна в виде глоссированных корпусов текстов и конкордансов на платформе lingvodoc. ispras.ru, диалектная принадлежность некоторых книг была установлена в более ранних публикациях, в этих случаях рядом с названием книги дана ссылка на статью, где приведено подробное обоснование):

- на казахском языке:1) северный диалект: [Букварь 1908²; Дыбо, Норманская 2016];

2) восточный диалект: [Крещение 1892; Дыбо, Норманская 2016];

3) западный диалект: [Премудрости 1893; Гаджиева 2019];

- на башкирском языке: 1) восточный диалект: [Учение 1899]
2) восточный диалект: [Евангелие $1902]^{5}$

3) восточный диалект: [Бессонов 1907; Экба, Норманская, Каримова 2019];

4) южный диалект: [Букварь 1892; Норманская, Каримова, Экба 2017];

- на татарском языке: 1) кряшанский казанский диалект: [Евангелие 1908; Нуриева 2015; Норманская, Нуриева 2018];

2) сергачский мишарский диалект: текст исповеди на языке сергачских мишарей XIX в. [Нуриева 2017];

3) чистопольский мишарский диалект: [Священная история 1862; Норманская, Нуриева 2018];

— на тубаларском языке: [ГАЯ 1869]; - на телеутском языке: [ГАЯ 1869].

Ниже в таблице 2 представлен полный список вариантов показателя множественного числа в словах с разными типами основ.

Таблица 2. Рефлексы *-lar/*-ler в первых кириллических книгах на кыпчакских языках в зависимости от типа основы

[Table 2. *- lar/*-ler reflexes in Cyrillic Kypchak books depending on the type of word's base]

\begin{tabular}{|c|c|c|c|c|}
\hline & \multicolumn{4}{|c|}{ Тип основ } \\
\hline $\begin{array}{c}\text { Языки и } \\
\text { диалекты }\end{array}$ & $-n,-\eta,-m$ & $-V$ & $-j$ & $-C_{2 \pi y x .}$ \\
\hline каз. лит. & $\begin{array}{c}-\boldsymbol{d} \boldsymbol{V} \boldsymbol{r} \\
\text { тұрвандарва } \\
\text { 'стоящим' }\end{array}$ & $\begin{array}{c}-\boldsymbol{l} \boldsymbol{V} \boldsymbol{r} \\
\text { кісілерi 'люди } \\
\text { его' }\end{array}$ & $\begin{array}{c}\text {-lVr } \\
\text { Үйлеріне } \\
\text { 'в их домах' }\end{array}$ & $\begin{array}{c}-\boldsymbol{t} \boldsymbol{V} \boldsymbol{r} \\
\text { жазықтарымды } \\
\text { 'грехи мои' } \\
\text { печенегтер 'печенеги' }\end{array}$ \\
\hline каз. сев. & $\begin{array}{c}\boldsymbol{d} \boldsymbol{V} \boldsymbol{r} \\
\text { бӧтендер } \\
\text { 'чужие' }\end{array}$ & $\begin{array}{c}-\boldsymbol{l V \boldsymbol { r }} \\
\text { балалар } \\
\text { 'дети' }\end{array}$ & $\begin{array}{c}\boldsymbol{l} \boldsymbol{V} \boldsymbol{r} /-\boldsymbol{d} \boldsymbol{V} \boldsymbol{r} \\
\text { койлар 'овцы' } \\
\text { уйлӧрине 'в их } \\
\text { дома' } \\
\text { уйдӧрине 'в их } \\
\text { домах' }\end{array}$ & $\begin{array}{c}\boldsymbol{d} \boldsymbol{V} \boldsymbol{r} / \boldsymbol{t} \boldsymbol{V} \boldsymbol{r} \\
\text { денгиздер 'моря' } \\
\text { айптар 'провинности' }\end{array}$ \\
\hline
\end{tabular}

${ }^{2}$ Книга [Букварь 1908] доступна он-лайн по ссылкам http:/lingvodoc.ispras.ru/dictionary/681/5/ perspective/681/9/view (глоссированный корпус), http://lingvodoc.ispras.ru/dictionary/1447/5/ perspective/1447/6/view (конкорданс).

${ }^{3}$ Книга [Премудрости 1891] доступна он-лайн по ссылкам http://ingvodoc.ispras.ru/dictionary/1752/7470/perspective/1752/7473/view (глоссированный корпус), http://ingvodoc.ispras.ru/dictionary/1752/7483/perspective/1752/7484/view (конкорданс).

${ }^{4}$ Книга [Учение 1899] доступна он-лайн по ссылкам http://ingvodoc.ispras.ru/dictionary/1700/5/ perspective/1700/8/view (глоссированный корпус), http://ingvodoc.ispras.ru/dictionary/1752/5/perspective/1752/6/view (конкорданс).

5 Книга [Евангелие 1902] доступна он-лайн по ссылкам http://lingvodoc.ispras.ru/dictionary/2479/8025/perspective/2479/8031/view (глоссированный корпус), http://ingvodoc.ispras.ru/dictionary/2519/16/perspective/2519/17/view (конкорданс). 
Oriental Studies. 2020. Vol. 13. Iss. 4

\begin{tabular}{|c|c|c|c|c|}
\hline каз. вост. & $\begin{array}{c}-\boldsymbol{d} \boldsymbol{V} \boldsymbol{r} \\
\text { дейсндер } \\
\text { 'действия' }\end{array}$ & $\begin{array}{c}-\boldsymbol{l V} \boldsymbol{r} /-\boldsymbol{d V} \boldsymbol{r} \\
\text { нӓрселер'вещи', } \\
\text { ксидери 'люди } \\
\text { его' }\end{array}$ & 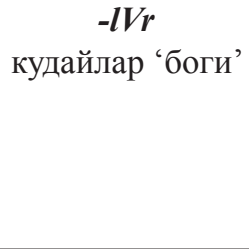 & $\begin{array}{c}-\boldsymbol{l} \boldsymbol{V} \boldsymbol{r} / \boldsymbol{- t} \boldsymbol{V} \boldsymbol{r} \\
\text { бӧктер 'бочки' } \\
\text { свящченниклерди 'священ- } \\
\text { ников' } \\
\text { печенеглер } \\
\text { 'печенеги' }\end{array}$ \\
\hline каз. зап. & 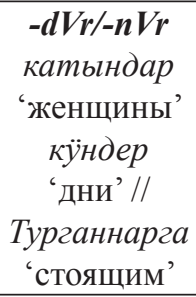 & $\begin{array}{c}\text {-lVr } \\
\text { балалар } \\
\text { 'дети' }\end{array}$ & 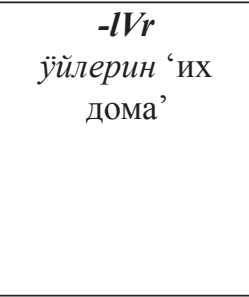 & $\begin{array}{c}\boldsymbol{l} \boldsymbol{l} \boldsymbol{r} /-\boldsymbol{d} \boldsymbol{V} \boldsymbol{r} / \boldsymbol{t} \boldsymbol{V} \boldsymbol{r} \\
\text { жазылларымды 'грехи мои' } \\
\text { сӧздер 'слова' } \\
\text { жемистер 'плоды' }\end{array}$ \\
\hline башк.вост. & $\begin{array}{c}-\boldsymbol{d V} \boldsymbol{r} \\
\text { дошмандар } \\
\text { 'враги' }\end{array}$ & $\begin{array}{c}\boldsymbol{l} \boldsymbol{V \boldsymbol { r }} \\
\text { балалар 'дети' } \\
\text { ауз̧арын 'силки' }\end{array}$ & $\begin{array}{c}\boldsymbol{- \boldsymbol { \delta } \boldsymbol { V } \boldsymbol { r }} \\
\text { бирмәйзәр } \\
\text { 'не дают' }\end{array}$ & $\begin{array}{c}-\boldsymbol{t} \boldsymbol{V} \boldsymbol{r} / \boldsymbol{\delta} \boldsymbol{V} \boldsymbol{r} \\
\text { бамлькктарына 'главам' } \\
\text { бдйгамбәрзљр } \\
\text { 'пророки' }\end{array}$ \\
\hline башк. южн. & $\begin{array}{c}\boldsymbol{- n V \boldsymbol { r }} \\
\text { дошманнар } \\
\text { 'враги' }\end{array}$ & $\begin{array}{c}\boldsymbol{l} \boldsymbol{l V} \\
\text { балалар 'дети' }\end{array}$ & $\begin{array}{c}-\boldsymbol{l V \boldsymbol { r }} \\
\text { бермайлар } \\
\text { 'не дают' }\end{array}$ & 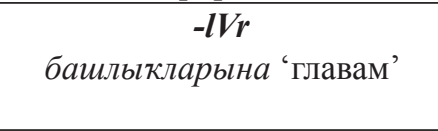 \\
\hline кряш. тат. & $\begin{array}{c}-\boldsymbol{n} \boldsymbol{V} \boldsymbol{r} \\
\text { 'враги' } \\
\text { 'враннар }\end{array}$ & $\begin{array}{c}\boldsymbol{l} \boldsymbol{V} \boldsymbol{r} \\
\text { жондозчыларь } \\
\text { 'звездочеты' }\end{array}$ & $\begin{array}{c}-\boldsymbol{l V \boldsymbol { r }} \\
\text { фарисейлярне } \\
\text { 'фарисеев' }\end{array}$ & $\begin{array}{c}\boldsymbol{l} \boldsymbol{V} \boldsymbol{r} \\
\text { ташлардан } \\
\text { 'из камней' }\end{array}$ \\
\hline тубалар. & $\begin{array}{c}-\boldsymbol{n V \boldsymbol { r }} \\
\text { јааннар } \\
\text { 'большие' }\end{array}$ & $\begin{array}{c}\text {-lVr } \\
\text { адалар } \\
\text { 'отцы' }\end{array}$ & & $\begin{array}{c}-\boldsymbol{l V} \boldsymbol{r} \\
\text { улуглар } \\
\text { 'большие' }\end{array}$ \\
\hline телеут. & 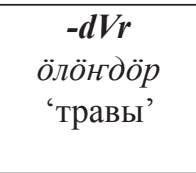 & 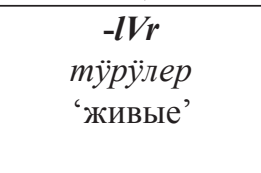 & $\begin{array}{c}-\boldsymbol{l V \boldsymbol { r }} \\
\text { кудайлар } \\
\text { 'боги' }\end{array}$ & $\begin{array}{c}-\boldsymbol{t} \boldsymbol{V} \boldsymbol{r} / \boldsymbol{d} \boldsymbol{V} \boldsymbol{r} \\
\text { кӧстӧр } \\
\text { 'глаза' } \\
\text { колдор 'руки' }\end{array}$ \\
\hline
\end{tabular}

3. Показатели множественного числа в первых кириллических книгах на кыпчакских языках в разных типах основ на картах

На карте 1 видно, что ареал языков с показателем множественного числа -dar в - $n,-\eta,-m$-основах, отмеченный голубым цветом, занимает более компактный ареал по сравнению с языкам с аффиксом -nar, что указывает на его инновационный характер. Наличие дублетных форм с -nar в первых кириллических книгах на западных казахских диалектах, которые уже не встречаются в современном западном костанайском диалекте, показывает, что процесс замены -nar на -dar был завершен только в XX в.

При этом реконструкция пракыпчакской формы аффикса для этой позиции все же затруднена, поскольку в караимском, каракалпакском, карачаево-балкарском, кумыкском языках представлена форма суффикса $-l V r$. Хотя нам неизвестны пер- вые кириллические книги на этих языках, но, учитывая, что в них сохранился архаичный вид показателя, можно предположить, что он был таким же и в XIX в. С другой стороны, и показатель -nar в этой позиции представлен в большинстве тюркских языков. Ниже при разборе пратюркской реконструкции формы аффикса в разных типах основы на карте 3 мы рассмотрим аргументы в пользу его появления в общетюркском языке.

Наличие показателей $-d V r,-\delta V r$ в основах на гласные и на -j являются очевидным образом инновационными, поскольку встречаются только в восточно-башкирских диалектах и спорадически - в северных и восточных первых казахских книгах.

Как можно видеть на карте 2, инновационный характер появления показателей множественного числа -t/dar еще более очевиден, поскольку дублеты в виде аффиксов -lar встречаются не только в западных, но и в восточных первых казахских книгах. 


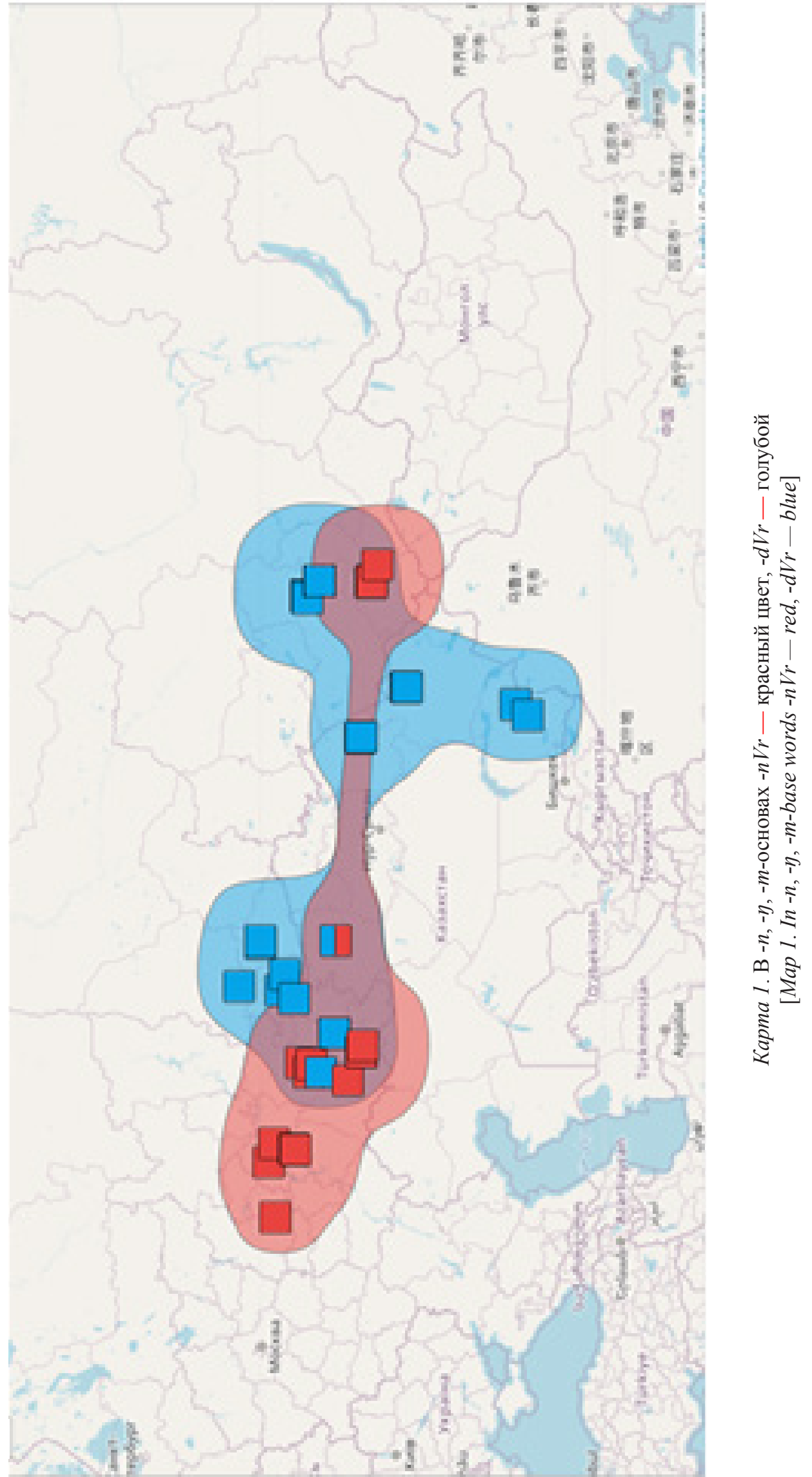


Oriental Studies. 2020. Vol. 13. Iss. 4

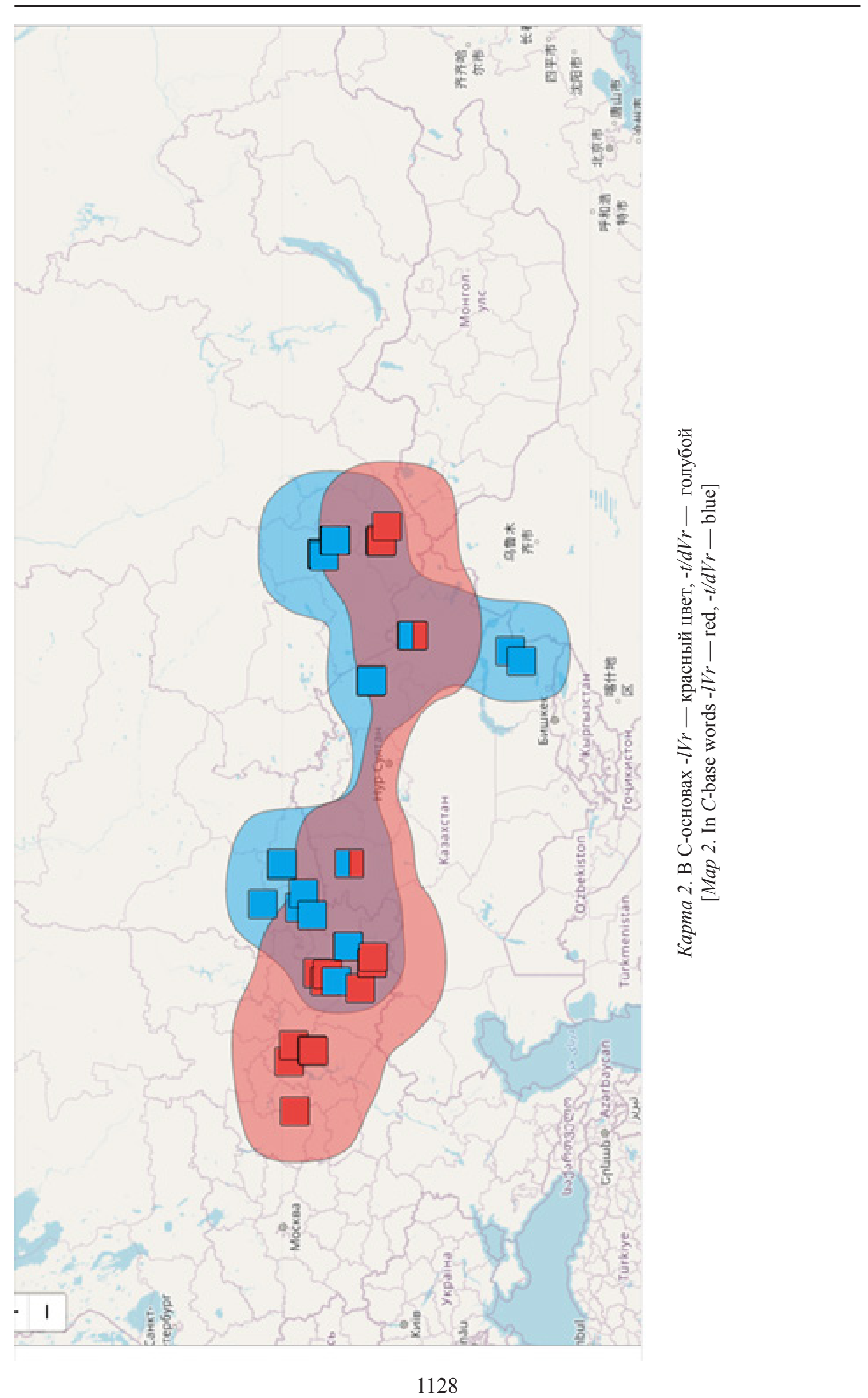


Эти факты, обнаруженные в ранее неописанных первых казахских книгах, являются подтверждением гипотезы О. А. Мудрака и А. В. Дыбо, высказанной в [СИГТЯ 2002: 603; СИГТЯ 2006: 229] о том, что появление показателя -t/dar в кыпчакских языках было инновацией, которая завершилась только в XX в.
4. Реконструкция показателей множественного числа в тюркских дочерних праязыках

Уточненная реконструкция пракыпчакских форм множественного числа позволяет обратиться к сравнению праязыковых форм суффикса для дочерних семей тюркских языков.

Таблица 3. Рефлексы *-lar/*-ler в дочерних тюркских праязыках в зависимости от типа основ

[Table 3. *- lar/*-ler reflexes in Turkic daughter languages depending on the type of word's base]

\begin{tabular}{|c|c|c|c|c|}
\hline & \multicolumn{4}{|c|}{ Тип основ } \\
\hline Языки & $*-n,-\eta,-m$ & $*_{-} V$ & $*_{-j}$ & $*_{-} C_{2 \pi v x}$ \\
\hline огузские & $*_{-n V r}$ & $*_{-}-l V r$ & $*_{-}-l V r$ & $*_{-}-l V r$ \\
\hline $\begin{array}{l}\text { карлукско- } \\
\text { уйгурские }\end{array}$ & $*_{-} l V r$ & $*_{-}-l V r$ & $*_{-} l V r$ & $*_{-} l V r$ \\
\hline кыпчакские & $*_{-} l V r /{ }^{*}-n V r$ & $*_{-} l V r$ & $*_{-} l V r$ & $*_{-} l V r$ \\
\hline кыргызские & $*_{-} n V r$ & $*_{-} l V r$ & $*_{-} l V r$ & $*_{-}-t V r$ \\
\hline тобаские & $*_{-n V r}$ & $*_{-} l V r$ & $*_{-} l V r$ & $*_{-t} t V r$ \\
\hline якутские & $*_{-} n V r$ & $*_{-} l V r$ & $*_{-} d V r$ & $*_{-}-t V r$ \\
\hline
\end{tabular}

\section{1. -n, -n, -m-основы}

Из таблицы 3 видно, что для типов основ *-n, - $\eta,-m$, опираясь только на генетическую информацию о тюркских языках, реконструировать пратюркский тип аффикса множественного числа сложно. Но наложение информации о форме показателя в разных тюркских языках на карту позволяет установить, что аффикс $-l V r$ в $-n$, - $\eta,-m$-основах встречается только в весьма ограниченном ареале на юго-западе распространения тюркских языков: от Крыма до Узбекистана (см. карту 3).

\section{2. -С-основы}

Для основ на $-\mathrm{C}_{\text {глух }}$, наоборот, генетическая принадлежность языка в большинстве случаев определяет рефлескацию показателя множественного числа как *-lVr (огузские, карлукско-уйгурские и часть кыпчакских языков) или *-tVr (часть кыпчакских языков, кыргызские, тобаские, якутский).
В большинстве случаев это соответствует и их географическому положению (см. карту 4).

На карте 4 видно, что пересечение этих ареалов как раз приходится на территорию распространению кыпчакских языков, в которых переход $-l V r$ в $-t V r$ происходил еще в XIX в.

\section{Выводы}

В результате проведенного анализа первых кириллических книг на тюркских языках мы приходим к выводу о правильности гипотезы Э. Р. Тенишева (ср.: [СИГТЯ 2002: 509]), который считал, что для позднепратюркского языка следует реконструировать аффикс множественного числа с модификациями в зависимости от типа основы.

На основании проведенного нами анализа можно предложить следующие правила морфонологических чередований (см. таблицу 4): 
Oriental Studies. 2020. Vol. 13. Iss. 4

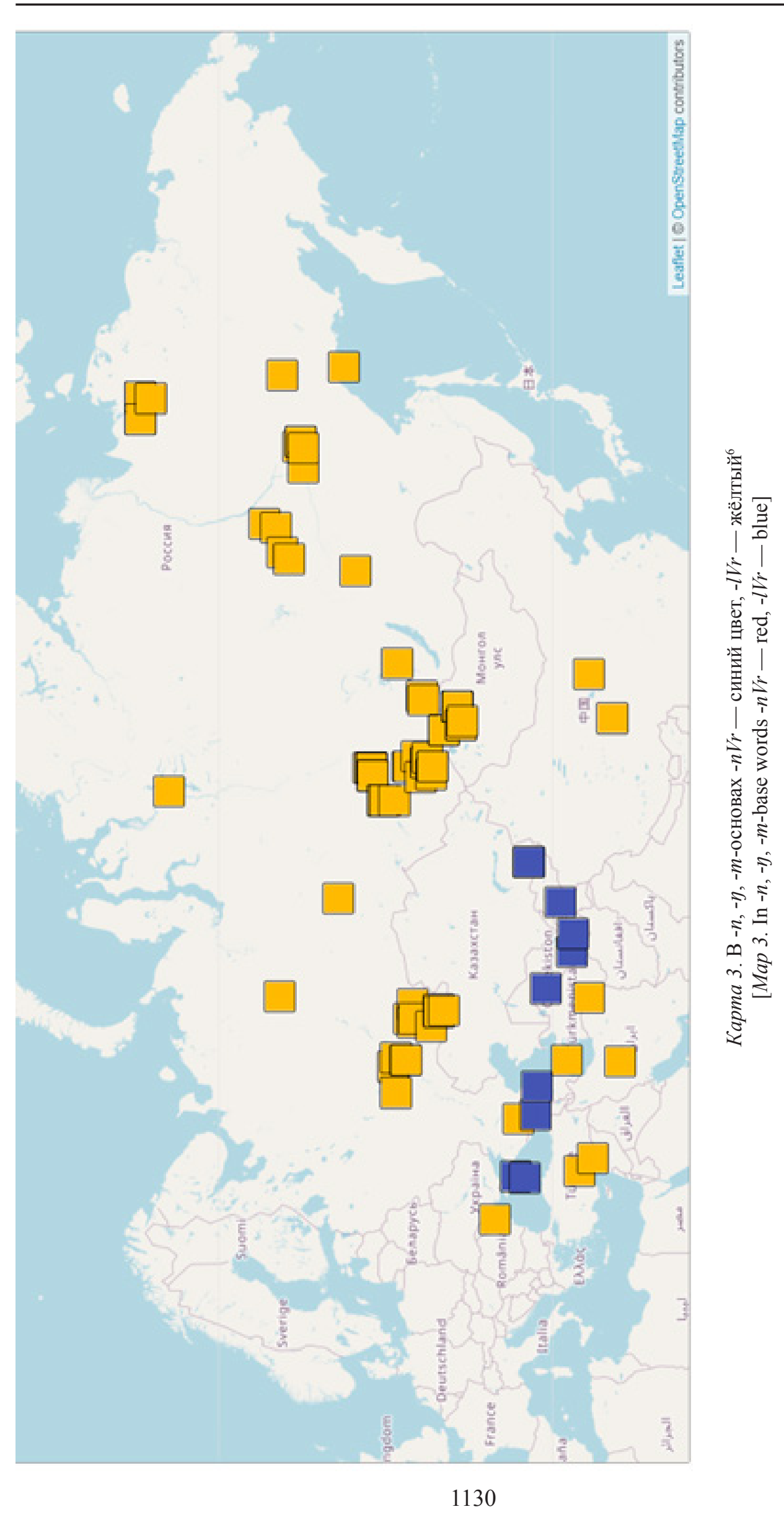




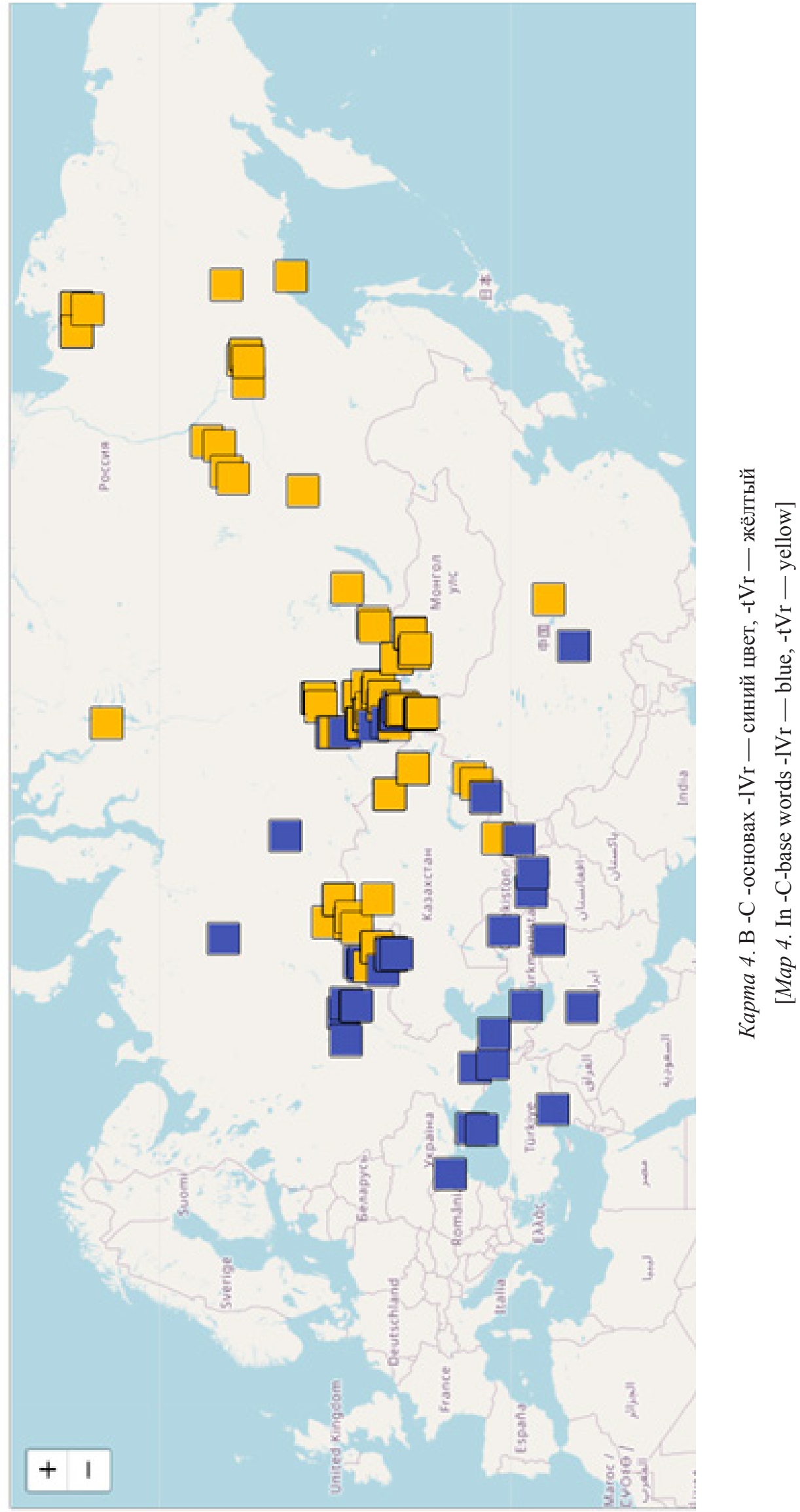


Таблица 4. Модификации*-lar/*-ler в позднепратюркском языке в зависимости от типа основы

[Table 4. Modifications of *-lar/*-ler in the late Turkic language depending on the type of base]

\begin{tabular}{|c|c|c|c|c|}
\hline & \multicolumn{4}{|c|}{ Тип основ } \\
\hline Язык & $*-n,-\eta,-m$ & $*_{-} V$ & $*_{-j}$ & $*_{-} C_{2700}$ \\
\hline позднепратюркский & $*-n V r$ & $*_{-} l V r$ & $*_{-} l V r$ & 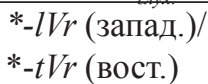 \\
\hline
\end{tabular}

В большинстве тюркских языков сохранилось позднепратюркское состояние аффикса множественного числа без изменений. В части кыпчакских языков (казахском, киргизском, некоторых диалектах башкирского и алтайского), которые находились на стыке территорий «-lVr vs.

\section{Сокращения}

азерб. - азербайджанский язык; алт. алтайский язык; башк. - башкирский язык; вост. - восточный; гагауз. - гагаузский язык; диал. - диалектный; зап. - западный; казах. — казахский язык; караим. - караимский язык; кбалк. - карабалкарский язык; кирг. киргизский язык; ккалп. - каракалпакский язык; крым-татар. - крымско-татарский язык; кряш. тат. - кряшенский татарский язык; кум. — кумыкский язык; лит. — литературный язык;

\section{Литература}

Бессонов 1907 - Бессонов А. Г. Букварь для башкир. Казань: Центральная типография, $1907.47 \mathrm{c}$.

Букварь 1892 - Букварь для башкир. Оренбург: типо-литография Бреслина, 1892. 58 с.

Букварь 1908 - Букварь для киргизъ. Букуар. Казань: Центральная типография, 1908. 37 с

Гаджиева 2019 - Гаджиева А. А. Анализ системы вокализма и консонантизма в первых кириллических книгах на казахском языке // Урало-алтайские исследования. 2019. № 3 (34).C. 53-71.

ГАЯ 1869 - Грамматика алтайского языка, составлена членами алтайской миссіи. Казань: Университетская типография, 1869. $298 \mathrm{c.}$

Дыбо, Норманская 2016 - Дыбо А. В., Норманская Ю. В. Первые кириллические книги на казахском языке как источники для изучения истории диалектов и создания литературной нормы // Урало-алтайские исследования. 2016. № 4 (23). С. 138-152.
- $t V r »$ произошла замена показателей *-lVr в $\mathrm{C}_{\text {глух }}$-основах и *-nVr в- $n,-\eta,-m$-основах на $*_{-} t V r$. Привлечение материала первых кириллических казахских книг позволило установить, что этот процесс был достаточно поздним и еще не был завершен в конце XIX в.

ног. - ногайский язык; салар. - саларский язык; сар.-юг. - сары-югурский язык; сев. северный; сев.-зап. - северо-западный; тат. татарский язык; телеут. - телеутский язык; тоф. — тофаларский язык; тубалар. - тубаларский язык; тув. - тувинский язык; турец. - турецкий язык; туркм. - туркменский язык; узб. узбекский язык; уйг. - уйгурский язык; хак. - хакасский язык; чулым. - чулымский язык; шор. - шорский язык; южн. - южный; якут. якутский язык.

Евангелие 1902 - Святое Евангелие (на башкирском языке). Казань: БИБО, 1902. 302 с.

Евангелие 1908 - Святое Евангелие Господа нашего Иисуса Христа на татарском языке. 3-е издание. Казань: Типография наследников М. А.Чирковой, 1908. 333 с.

Каримова, Латыпова 2016 - Каримова Р. Н., Латыпова Р. М. Письменные источники по башкирскому языку конца XIX - начала XX века // Урало-алтайские исследования 2016. № 1 (20). С. 41-52.

Крещение 1892 - Ауліе княз Владимир тура динге бзи де крип; орыс калкын-да кргизгени. Крещение Руси на киргизскомъ языке. Казань: Типография наследников М. А. Чирковой, 1892. 27 с.

Норманская, Каримова, Экба 2017 - Норманская Ю. В., Каримова Р. Н., Экба 3. Н. В. В. Катаринский - автор первой книги на башкирском языке? // Урало-алтайские исследования. 2017. № 2 (33). С.46-52.

Норманская, Нуриева 2018 - Норман-

${ }^{6}$ На этой карте не показана информация об ареале языков с показателем множественного числа $-d V r$ в $n-, m-, \eta$, потому что, как было показано выше, этот вариант аффикса является инновацией. 
ская Ю. В., Нуриева Ф. Ш. Диалектные особенности первых кириллических книг на татарском языке // Вопросы тюркской филологии. Материалы Дмитриевских чтений, посвященные памяти Д. М. Насилова. М.: Изд-во МГУ, 2018. С. 95-113.

Нуриева 2015 - Нуриева Ф. Ш. Диалектная основа книг на «крещено-татарском» языке второй половины XIX века // Урало-алтайские исследования. 2015. № 2 (17). С. 67-73.

Нуриева 2017 - Нуриева Ф. Ш. Языковой памятник говора сергачских мишарей: текст исповеди XIX века // Урало-алтайские исследования. 2017. № 3 (26). С. 161-173.

Премудрости 1891 - Акыл бере тугун кнеге (Изъ премудрости Іисуса сына Сирахова). Казань: Тип. и Литогр. В. М. Ключникова, $1891.55 \mathrm{c}$.

Священная история 1862 - Священная история от сотворения мира до кончины Иосифа по книге Бытия, изложенная на народном татарском языке. Казань: [б. и.], 1862. 137 с.

СИГТЯ 2002 - Сравнительно-историческая грамматика тюркских языков. Региональные реконструкции / под ред. Э. Р. Тенишева. М.: Наука, 2002. 769 с.

\section{References}

Bessonov A. G. ABC book for the Bashkirs. Kazan: Central typography, 1907. 47 p (In Bashkir.)

ABC book for the Bashkirs. Orenburg: type-lithography of Breslin, 1892. 58 p. (InBashkir.)

ABC book for the Kyrgyzes. Bukuar. Kazan: Central typography, 1908. 37 p. (In Kyrgyz.)

Grammar of the Altai language, compiled by members of the Altai mission. Kazan: University typography, 1869. 298 p. (In Russ.)

The Holy Gospel in the Bashkir language. Kazan: BIBO, 1902. 302 p. (In Bashkir.)

Holy Gospel of Our Lord Jesus Christ in the Tatar language. Kazan: typography of M. A. Chirkova's heirs 1908. 333 p. (In Tatar.)

Karimova R. N., Latypova R. M. Written sources in the Bashkir language of the late $19^{\text {th }}$ - the early $20^{\text {th }}$ century. Ural-Altaic Studies. 2016. No 1 (20). Pp. 41-52. (In Russ.)

Cristianization of Russia in the Kirghiz language. Aulie kn'az Vladimir tura dinge bzi de krip; orys kalkyn-da krgizgeni. Kazan: typography of M. A. Chirkova's heirs, 1892. 27 p. (In Kyrgyz.)

Nurieva F. Sh. The dialectal base of the books written in "christened Tatar" in the latter half of the
СИГТЯ 2006 - Сравнительно-историческая грамматика тюркских языков. Пратюркский язык-основа. Картина мира пратюркского этноса по данным языка / под ред. Э. Р. Тенишева и А. В. Дыбо. М.: Наука, 2006. 912 с.

Турсунова 2012 - Турсунова М. А. О формах множественного числа в тюркских языках: синхронический и диахронический аспекты // Филологические науки. Вопросы теории и практики. Тамбов: Грамота, 2012. № 3. C. 93-95.

Учение 1899 - О загробной жизни по учению Православной церкви на башкирском языке. Казань: Типо-литография императорского университета. 1899. 79 с.

Шаймердинова 2016 - Шаймердинова Н. Г. Анализ системы консонантизма в казахских памятниках конца XIX - начала XX вв. // Урало-алтайские исследования. 2016. № 4(23). С. 128-137.

Экба, Норманская, Каримова 2019 - Экба 3. Н., Норманская Ю. В., Каримова Р. Н. Три диалекта в «Букваре для башкир» А. Г. Бессонова // Урало-алтайские исследования 2019. № 2 (33). С. 101-111.

$19^{\text {th }}$ century. Ural-Altaic Studies. 2015. No 2 (17). Pp. 67-73. (In Russ.)

Nurieva F. Sh. A linguistic monument of the Sergach Mishars' dialect: a confession text from the $19^{\text {th }}$ century. 2017 . No 3 (26). Pp. 161-173.

Ak1l bere tugun knege. From the book of Wisdom of Sirach. Kazan: V. M. Kljuchnikov's typography and lithography, 1891. 55 p. (In Kyrgyz.)

The Sacred history from the creation of the world to the death of Joseph according to the book of Genesis, in the Tatar language. Kazan, 1862. 137 p.(In Tatar.)

Comparative-historical grammar of Turkic languages: Regional reconstructions. E. R. Tenishev (ed.). Moscow: Nauka, 2002. 769 p. (In Russ.)

Comparative-historical grammar of Turkic languages. Proto-Turkic base language. A Proto-Turk's world-view. E. R. Tenishev \&A. V. Dybo (ed.). Moscow: Nauka,2006. 912 p. (In Russ.)

Tursunova M. A. About plural forms in Turkic languages: synchronistic and diachronic aspects // Philological Sciences. Theory and practice. Tambov: Gramota, 2012. No 3. Pp. 93-95. (In Russ.)

On the afterlife according to the teachings of the Orthodox Church in the Bashkir language. 
Kazan:Typography of Imperator's University, 1899. 79 p. (In Russ.)

Shajmerdinova N. G. Analysis of consonant system in the Kazakh written monuments of the late $19^{\text {th }}$ and early $20^{\text {th }}$ centuries. Ural-Altaic Stud- ies. 2016. No 4 (23). Pp. 128-137. (In Russ.) Ekba Z. N., Normanskaya Yu. V., Karimova R.N. Three dialects in the "Primer for Bashkirs" by A. G. Bessonova / / Ural-Altai Studies 2019. No. 2 (33). pp. 101-111.(In Russ.) 